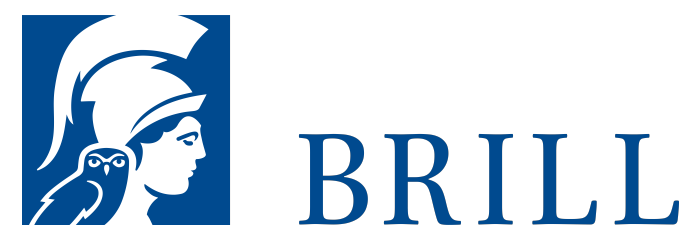

\title{
Biblische Gestalten im Jüdischen Religionsunterricht
}

Bilderbücher und Konzepte zur religiösen Erziehung

Author: Susanne Lechner-Masser

Wie verstehe ich die Welt? Wie lebe ich den Alltag? Religion als gefühltes, den Alltag prägendes Selbstverständnis bestimmt Grundhaltungen, Verstehensmuster, Bindungen und Handlungsimpulse. Für die Erziehung zu Religion werden im christlichen wie im jüdischen Kontext biblische Texte und Tradition vermittelt.

Ausgewählte Beispiele geben Einblick in die Erziehungswelt jüdischer Kinder. Sie regen an, vertraute biblische Figuren einmal ganz anders zu betrachten und in weitgehend unbeachteten Texten der christlichen Bibel jüdische Texte voll Leben zu sehen. Dabei wird in Reflexion der eigenen Tradition christlichen Lesern jüdisches Selbstverständnis und jüdische Lebensweise nahegebracht. Durch den vergleichenden Blick ist dies ein Buch für christliche wie für jüdische LeserInnen.

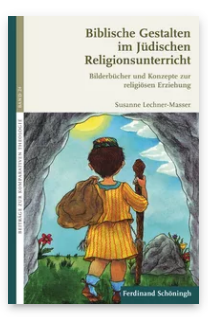

Pages: 292 Seiten, $31 \mathrm{~s} / \mathrm{w}$ und 72 farb. Abb. Language:

German

Subjects:

General, Theology and

World

Christianity

Publisher: Brill | Schöningh

Series:

Beiträge zur

Komparativen

Theologie,

Volume: 24

E-Book (PDF)

Released online:

O5 Oct 2017

ISBN: $978-3^{-}$

657-78468-4

List price

Paperback

Publication date: o8 Sep 2017

ISBN: 978-3506-78468-1

List price 
Susanne Lechner-Masser, ist Pfarrerin der Evangelischen Pfarrgemeinde Bischofshofen- St. Johann. Sie ist Beauftragte für das christlich-jüdische Gespräch der Diözese Salzburg-Tirol und Mitarbeiterin im Arbeitskreis Rabbinen und Kirchenväter Wien- Salzburg sowie Mitglied der Österreichisch-Israelischen Gesellschaft.

For more information see brill.com

Order information: Order online at brill.com +44330 3330049 | customerservices@brill.com Submission information: brill.com/authors

Titles published by Brill | Fink, Brill | mentis or Brill | Schöningh: +49(o)71 5413279216 | brill@brocom.de 